\title{
Stereotypes of China and Chinese in the Hundred Secret Senses
}

\author{
Yu Ma \\ Gansu Normal University for Nationalities, Hezuo, Gansu, China
}

Keywords: The Hundred Secret Senses; orientalism; Amy Tan.

\begin{abstract}
In the orientalist discourse system, the occident constructed its own superiority through various negative discourses about the Orient. Under such constructions, the occident is superior politically, economically and culturally while the orient is of poverty, chaos and barbarity. Due to her familial environment and Chinese American identity, Amy Tan has consciously or unconsciously reconstructed such stereotypes of China and Chinese in her novel, The Hundred Secret Senses. This paper discusses stereotypes of China and Chinese in the novel and points out that these stereotypes are the products of the collective imagination of the Western society.
\end{abstract}

\section{Introduction}

The Hundred Secret Senses is one of the masterpieces by the famous Chinese-American writer Amy Tan. The novel attracted hundreds of thousands of readers after its publication in 1995 and remained on the New York Times best-seller list for Three months and was short-listed for the Orange Prize for Fiction in 1996. Orientalism put forward by the well-known critic and Orientalist Edward Said in his masterpiece Orientalism is a theoretical cornerstone for the Postcolonial criticism. In the Orientalist discourse system, the Occident constructed its own superiority through various negative discourses about the Orient. Under such constructions, the Occident is superior politically, economically and culturally while the Orient is of poverty, chaos and barbarity. Due to her Chinese American identity, Amy Tan has consciously or unconsciously reconstructed such stereotypes of China and Chinese in her novel The Hundred Secret Senses.

\section{A Brief Introduction to Orientalism}

The term "Orientalism" is used by art historians, literary and cultural studies scholars for the imitation or depiction of aspects in Middle Eastern, and East Asian cultures. Since the publication of Edward Said's Orientalism in 1978, much academic discourse has begun to use the term "Orientalism" to refer to a general patronizing Western attitude towards Middle Eastern, Asian and North African societies. According to Said, Orientalism is a style of thought based on an ontological and epistemological distinction made between the Orient and the Occident. "Thus a very large mass of writers... have accepted the basic distinction between East and West as the starting point for elaborate theories, epics, novels...concerning the Orient, its people, customs..." (Said, 1978: 2) One of the distinguished characteristics of Orientalism is to construct the Orient out of the Westerners' ignorance, prejudice, curiosity. "the Orient was almost a European invention, and had been since antiquity a place of romance, exotic beings, haunting memories and landscapes, remarkable experiences" (Ibid 1). Under such constructions, the Occident is superior politically, economically and culturally while the Orient is of poverty, chaos and barbarity. In fact, the Orient is the constructed product of imagination and creation by the Occident and the western mainstream culture has always been creating, maintaining and intensifying the stereotypes of the Orient.

According to Said, "The Oriental is irrational, depraved (fallen), childlike, different; thus the European is rational, virtuous, mature, normal." (Ibid 40) Such a binary opposition has exerted a significant influence on Chinese American writers who have accepted the basic distinction between the East and the West as the starting point for elaborate accounts concerning the Orient and its people, which can be called "cultural hegemony" in Antoni Gramci's words. As a result, the strongly 
influenced Chinese American writers consciously or unconsciously presented an even more vivid portrayal of Orientalism in their works. Amy Tan's novel The Hundred Secret Senses constructed the stereotyped China and Chinese people in the discourse of Orientalism.

\section{Stereotypes of China}

In The Hundred Secret Senses, Amy Tan sets part of her stories in China in two centuries with Kwan's past life in the nineteenth century and the half-sisters present life in the twentieth century, whereby the description of China constructed the stereotypes of the Orient.

\subsection{Urban and Rural China in the Late 20th Century}

As far as Said was concerned, the Orient is a fictional invention by the Westerners out of their ignorance, prejudice, curiosity about the Orient. As long as the Westerners are concerned, the Orient is either ugly, backward and dark or mysterious, beautiful and exotic. Such stereotypes and hegemony culture is very pervasive. China depicted in The Hundred Secret Senses is romanticized, vilified, feudal, and violent, which conform to the image of Other in the eyes of the Westerners. In the description about Guilin, one of China's most beautiful cities, Amy Tan neglects everything concerned with its modernization and civilization and only cares about its pollution. Guilin is vilified as an ugly-looking city with "industrial pollution", "garish-red sign-boards", "prewar houses", and "impromptu garbage dumps". While at the very moment they arrive in the village Changmian, they were attracted by the beautiful landscape and its primitiveness. They find a paradise here in the East.

"a village nestled between two jagged peaks, their hillsides a velvety moss-green with folds deepening into emerald...Miraculously, Changmian has avoided the detritus of modernization...Clean stone pathways crisscross the village, then thread up a cleft between the two peaks and disappear through a stone archway. In the distance is another pair of tall peaks, dark jade in color, and beyond those, the purple shadows of two more." (Tan, 2004: 184)

Obviously, Guilin and Changmian in the novel are just the Orientalized stereotypes of urban and rural China that is in accordance with the Westerners' expectation. Just as Huang Hewei (2004) said "Westerner's knowledge about China is always a mix of reality and imagination. China's image in the eyes of the Westerners mainly depends on the West's own needs and problems, not on China's reality."

\subsection{A War-suffering China in the Nineteenth Century}

Tan sets part of her story at the time of the Taiping Rebellion which began in 1850 during the Qing dynasty and violently ended in 1864. In describing the cruelty of the war and Chinese people's miserable life under war, Amy Tan presents her readers a China of violence, blood and upheaval, which makes a sharp contrast with the 20th century America where people live in peace and prosperity.

"Ten years before, the Heavenly King had sent a tide of death from the moutains to the coast. Blood flowed, millions died. Now the tide was returning. In the port cities, the Manchus had slaughtered all the God Worshippers. They were moving inland, burning down houses, digging up graves, destroying heaven and earth at the same time." (Tan, 2004: 193)

Because of the war, starvation was pervasive in China and people began to look for everything that can be eaten as their food.

"Every day Lao Lu and I searched for food...We sat in the kitchen at night, waiting for insects and rats to come out for crumbles we couldn't see...In the spring time, we plucked locusts and grasshoppers hatching in the fields. We found frogs and grubs and bats..." (Tan, 2004: 166)

Such descriptions give the Westerners an impression that China under war in the nineteenth century was in extreme trouble and hell-like compared with the paradise-like modern America. But Amy Tan's knowledge about the Taiping Rebellion is not necessarily objective. According to Rudolf G. Wagner, the Taiping Rebellion is "the most important rebellion of the nineteenth century" and he attributes the causes for this "best documented rebellion in Chinese imperial history" to "the friendly contact sought by many missionaries and by the Taipings themselves."(Wagner, 1982: 1-2) Whereas, 
Sheng-mei Ma (2000: 115) thinks that "to suggests that the Taiping uprising is the 'best documented rebellion' implies a Eurocentrism whereby only source materials in Western languages seem to matter. Amy Tan's interest is aroused, no doubt, by the abundant materials in English and, in particular, by the role of the missionary in the event." Therefore, Amy Tan has got materials about the Taiping Rebellion in an indirect way and her reproduction about it was an invented one in the Orientalist way. All these negative descriptions about old China seem to implicate that for the Chinese people, the only way to escape from their miserable life is to emigrate from China to America, which testifies the Oriental imagination and expectation. Kwan, Nunumu in the period of the Taiping Rebellion, immigrated to America in the late twentieth century which completely met such imagination and expectation.

\section{Stereotypes of Chinese}

Amy Tan created many woman characters and several man characters in The Hundred Secret Senses. But her characterization was doubtlessly influenced by the Westerner's prejudices about Chinese people. This part will explore the stereotypes of Chinese woman and Chinese man.

\subsection{Stereotypes of Chinese Women}

As one of the narrators in The Hundred Secret Senses, Kwan "had a sad but fascinating life." (Tan, 2004: 7) Both in her previous life as Nunumu or in her current life as Kwan, she played/plays the role of a servant to the Westerners which caters to the tastes of the Westerners, highlights their superiority and construct the master-servant relationship between the West and the East. Just have a look at what Nunumu did every week.

"On the First Day of each week I had to wash. On the Second Day, I ironed what I had washed. The Third Day was for polishing shoes and mending clothes. The Fourth Day was for sweeping the courtyard and passageways. The Fifth Day for mopping the floors and wiping the furniture in God's house. The Sixth Day was for important business." (Ibid 67)

In her current life, Kwan came to America when she was eighteen years old and lived with her half-sister Olivia in San Francisco where she again played the role of a servant and babysitter to this modern American family, which can be seen from the monologue of Olivia. "To Mom, Kwan was a handy baby-sitter, willing, able, and free." (Ibid 9)

Amy Tan took great efforts to portray an image of servant from China. Whether it is in the past or in the present, the image of Chinese has never changed. The Orientals are always inferior compared with the arrogant Westerners and willing to be the Westerners' servants which are in accordance with their identity of Otherness. Moreover, in the eyes of Orientalists, as inferior Others, the Orientals should be in service with the Whites. For the interests of the Whites, the Others should sacrifice their own interests, including their love and even their life. In her previous life, Nunumu voluntarily sacrificed her own love and life in order to save the missionaries. In her present life, in order to reunite Olivia and Simon from their estranged marriage, Kwan went into the cave in Changmian and saved Simon's life and their marriage with the sacrifice of her own life.

\subsection{Stereotypes of Chinese Men}

At the very beginning of The Hundred Secret Senses, Tan designed the plot of the father's death. In such a secretive way, Tan exiled father, a symbol of fertility and creativity outside the text. Like Tan's other novels, the main characters who are present in his novel are also female ones while the men characters are almost absent. Even if occasionally there are some men, they don't have any discourse power. The western mainstream culture does everything to demonize the Chinese men, making negative stereotypical image of Chinese men firmly rooted in the minds of Westerners. The few Chinese in The Hundred Secret Senses are all negative characters who are ignorant, rude, dishonest, and feminized.

The driver Rocky has a set of nicotine-stained teeth and says in heavily accented English. His late-model sedan curiously lacks seat belts and safety headsets. On their way from Guilin to Changmian, Rocky tells his passengers his dream, 
When I live in America, I'll save most of my money, spend only a little on food, cigarettes, maybe the movies every now and then, and of course a car for my taxi business. My needs are simple. After five years, I'll have almost one hundred thousand American dollars. Here that's a half-million yuan, more if I exchange it on the streets. Even if I don't become a movie star in five years, I can come back to china and live like a rich man. (Ibid 178-179)

But this beautiful dream is taken as ignorance by his western passengers. Simon asks Olivia to tell Rocky that "most people would probably starve in America on fifty dollars a day" (Ibid 179).

When their car passes a bad accident, Olivia wants to stop the car and help the victims but Rocky doesn't stop and drives forward and tells them later they can do nothing to help. Simon can't understand that there's no ambulance, no doctors at the accident scene at all. By this plot, Tan reveals to her western readers a rude, indifferent Rocky who violates the human rights advocated by the Westerners.

The Chinese Exclusion Act issued in 1882 made the Chinese highly marginalized in the United States. In order to survive, many Chinese men had to engage in the service industries disdained by some white men, such as waiters, cooks, housekeepers, laundrymen, which were regarded by some Westerners as professions only suitable for women. As a result, the image of most Chinese men was feminized and castrated. Kwan's bother-in-law was a former chemist, but after he migrated to the United States, he worked as a dishwasher because "he is too scared to speak English lest people think he is stupid." Kwan's husband George "has just been promoted to manager at a Food-4-Less store in the East Bay." (Ibid 127)

These images of men are actually the stereotyped sexual concept of Orientalism. In other words, this is Tan's imaginative portray of the Oriental male with the standards of the Western men. Tan's literary success in the western society is at the expense of the dignity of self-ethnic male."( $\mathrm{Li}, 2011$ : 7)

Chen Aimin (2004: 78) argues that "In the Orientalist discourse, Chinese men are castrated, feminized and homosexualized in some American literary works and are legally and ideologically excluded from the ranks of Americans." Besides, Kwan and Olivia's father Jack Yee is another vilified Chinese male image in the novel. He stole his name Jack Yee from another drunken theft and discarded his wife and daughter and immigrated alone to America with the stolen name and a stack of official documents for immigration. Lao Lu is an old man with "bald head, strong arm, strong leg, and strong temper" and was beheaded due to his loose temper.

All these male figures above are negative. These images satisfy the Westerners' views about Chinese men and verify their established prejudices against Chinese men. To the Westerners, Chinese men are weak, lazy and cruel, who are the Others excluded from law and ideology. Under the influence of such Orientalist collective identity, Tan's portray of Chinese men reveals her view of stereotypical China, and support the views of Orientalism.

Compared with the image of Chinese men being feminized and castrated and timid, most American men in the works of Tan appear in a positive image of being tall, masculine, self-confident, elegant, civilized. In The Hundred Secret Senses, Tan portrays such an American man character to make a sharp contrast.

Simon strides off, and I notice how American his swagger looks, especially here on foreign soil. He walks in his own rhythm; he doesn't conform to the crowd. (Tan, 2004: 175)

From the above discussion, we can see that China and Chinese depicted in The Hundred Secret Senses are not true. They are just the constructed images by Amy Tan. As a matter of fact, by such depictions, Tan unconsciously reinforced the negative stereotypes of the Orient. After all, Tan is an American-Born-Chinese who often believe themselves as American in spite of their yellow skin.

\section{Conclusion}

According to Edward Said, the Orient is not generated from facts or reality, but is imagined by the Occidentals. Under such an imagination, all "Eastern" societies are fundamentally similar to one another, and fundamentally dissimilar to "Western" societies. The Orient is placed at an inferior position to the Occident. Anything positive, rational, civilized are Occidental; whereas, anything 
negative, irrational, uncivilized are Oriental. The dual cultural background of Amy Tan makes her literary creation full of contradictions and paradoxes. On one hand, she must resist against Orientalism with the help of her homeland culture when establishing her own ethnic identity. On the other hand, she cannot get rid of the domination of American mainstream ideology. As a result, she consciously or unconsciously exaggerated the difference between China and America and constructed stereotypes of Orientalized China and Chinese people in The Hundred Secret Sense in order to cater to the taste of the Westerners. When we read and learn Chinese-American literature, we should give up dualism and adopt multidimensional perspectives to make an objective and fair evaluation.

\section{References}

[1] Chen, Ai-min. Orientalism and the Construction of Male Images in Chinese American Literature[J]. Foreign Literature Studies, 2004 (06)

[2] Huang He-wei. The Perfect Image of China in the eyes of Westerners: Comment on Lost Horizon from the Perspective of Orientalism[J]. Journal of University of Science and Technology Liaoning, 2009(3)

[3] Li, Li. Self-orientalism and Anti-orientalism: The Construction of Cultural Identity in Amy Tan's Novels [D]. Nanchang: Jiangxi Normal University, 2011

[4] Ma, Sheng-mei. The Deathly Embrace: Orientalism and Asian American Identity. Minneapolis: University of Minnesota Press, 2000

[5] Said, Edward. Orientalism. New York: Vintage Books, 1978

[6] Tan, Amy. The Hundred Secret Senses London: Harper Perennial, 2004

[7] Wagner, Rudolf G. Reenacting the Heavenly Vision: The Role of Religion in the Taping Rebellion. Berkeley: University of California Press, 1982 